\title{
Answers to the Official Statement of SSKM-SSU (UK) to Uqbah Iqbal's Article
}

\section{Uqbah lqbal*}

School of History, Politics and Strategy, Faculty of Social Sciences and Humanities, UKM 43650, BangiSelangor, Malaysia

Before this, I had published an article entitled "Opinion on SSKM and Sabah Country Myth" in Arts and Social Sciences Journal, Volume 7, Issue 2, 2016 [1]. An official statement issued by Sabah Sarawak Union - United Kingdom (SSU-UK) on 9 September 2016 [2], and the case went viral on facebook. I will elaborate on my article to resolve all the questions raised. Before that, let me explain the methodology of history. Writing is to use screening and writing methods from the point of history. This means that the subject matter of the study is the use of resources, especially archive files and data from government organizations, whether printed or not printed. The initial phase of the research is to identify and collect resources. This is done by conducting research in libraries, archives and government organizations as well as by means of external studies. In the second stage the researcher make verification and manipulation of resources. The results of the information obtained is assessed and analyzed by the researcher and this understanding is the third stage in the process of research which makes interpretation of sources. At the same time, the researcher also compiled resources according to priorities and the extent of the contribution of these sources to writing later. Finally writing made and this is the last stage in the research process [3]. Dear Doris Jones as founder of Sabah Sarawak Union - United Kingdom, did you follow all these rules? The answer is NO.

For the first question from you, the status of England, Scotland, Wales and Northern Ireland is a country in the United Kingdom of Great Britain and Northern Ireland. Country in terms of culture in English called a nation, country in terms of geographical in English called a country and country in terms of politics in English called a state. But seeing the country definition in the Oxford dictionary is not enough [4]. Your understanding confusion concerning the country means negara entirely in Malay Language because in English Language, sometimes the word country is used to refer both to sovereign states and to other political entities, while other times it refers only to states. For example, the CIA World Factbook uses the word in its "Country name" field to refer to "a wide variety of dependencies, areas of special sovereignty, uninhabited islands, and other entities in addition to the traditional countries or independent states" [5]. According to Dewan Bahasa dan Pustaka Dictionary, definition of negara is a group of people who inhabit an area, have political sovereignty and government machinery (18). The meaning of sovereignty is the exclusive right to fully master an administrative area and the people. Where is Sabah's sovereignty as a country once under the rule of the Sultanate of Brunei, the Sultanate of Sulu, North Borneo Chartered Company, the Japanese and British before the formation of Malaysia in 1963?

As you know the Malay Language is different from the English Language. In fact, every language in the world is different between one another. Dear Doris, you have a serious linguistic problem on this issue. The country words used by authors in your references are by their grammatical understanding, not ours. Let me explain in simple languages. Country, nation and state (in some cases), all of which means negara in the Malay Language. But we have to know the difference meaning despite only that word is available. Although the status of England, Scotland, Wales and Northern Ireland is a country in the United Kingdom of Great Britain and Northern Ireland, but if the country word was translated into the Malay Language, it means wilayah because each of them are not sovereign states according to international law. The country word is used to refer political entities within the United Kingdom of Great Britain and Northern Ireland $[6,7]$. Strictly speaking, a country is not necessarily the same thing as a sovereign state [8]. Why I use the word country in the first article as it is translated from negara in the Malay language. Maybe next time I should change it to a sovereign state, which means negara berdaulat in the Malay language for deeper understanding.

To establish a new country that according to the concept of a sovereign state in the Malay language, there are various aspects that should be followed and I'll touch on some key aspects, namely the country must first satisfy the international laws rules that all free countries generally acknowledge and follow set forth by the Montevideo Convention on the Rights and Duties of States, adopted in 1933. The Montevideo Convention requires that a country must declare its intentions. The country must be able to enter into relations with other sovereign states. In order to be legitimate, a new country must be recognized by existing states within the international community. The United Nations asserts that, because it itself is not a country, it does not possess any authority to recognize a state or government. But being admitted into the U.N. goes a long way toward a new country becoming recognized by the international community [9]. Through all of this method, do North Borneo before the formation of Malaysia ever through it? The answer is NO. Have even one country in the world recognize North Borneo as a sovereign state? The answer is NO.

Dear Doris, now I will comment on the resources you use. You'll find we're both using the same source but you interpret it at will. W.H. Treacher, C.M.G., M.A. Oxon in the article "British Borneo: Sketches of Brunai, Sarawak, Labuan and North Borneo" explain "A British Protectorate was established over North Borneo on the 12th May, over Sarawak on the 14th June, and over Brunai on the iyth September, 1888" on page 6 [10]. Rizal Zamani Idris, Bilcher Bala and Azizan H. Morshidi in the article "Sabah (Malaysia) - Australia Relations: An Historical Observation" said "Sabah gained its independence through the concept of "federation of colonies", which was a merging of the Malayan Federation, Singapore, and Sarawak to form the Malaysian Federation in 1963" on page 152 and "In 1946, the ruling of Sabah and Sarawak was given to the British government with the major

*Corresponding author: Iqbal U, School of History, Politics and Strategy, Faculty of Social Sciences and Humanities, UKM 43650, BangiSelangor, Malaysia, Tel: +60389215555; E-mail: uqbah@siswa.ukm.edu.my

Received September 14, 2016; Accepted September 23, 2016; Published October 01, 2016

Citation: Iqbal U (2016) Answers to the Official Statement of SSKM-SSU (UK) to Uqbah Iqbal's Article. Intel Prop Rights. S1: 001. doi: 10.4172/2375-4516.S1-001

Copyright: @ 2016 Iqbal U. This is an open-access article distributed under the terms of the Creative Commons Attribution License, which permits unrestricted use, distribution, and reproduction in any medium, provided the original author and source are credited. 
intend to redevelop the colonies that have been destroyed during the war." on page 160 [11]. Tom Harrisson in the article "The Prehistory of Borneo" said "These three territories were each separate colonies under British rule during most of that period" on page 17 [12]. If we look at Whelan's writing in the book "Stories from Sabah History", it is suitable for students from form 2 and 3, is it relevant to academic discussions at the highest level? [13] Stockwell in the book "Malaysia", said "Of the participating countries, only North Borneo and Sarawak were crown colonies, and, in a manner of speaking, only North Borneo and Sarawak were being decolonised. Indeed, as the final touches were put to Malaysia, the British presented it to the United Nations, not as a new state, but as an extension of an existing member-state, that is to say an extension of the independent Federation of Malaya to which Sabah (North Borneo), Sarawak and Singapore merely acceded" in the introduction [14].

Dear Doris, you only display 5 resources, 4 from British and one from Malaysia to strengthen the argument of Sabah is a country, while I display 19 sources, with 7 from Malaysia including Sabah authors. Isn't it weird when discussions about your own country, you may glorify the use of foreign sources of local people? The writing of history is to be written objectively, founded by Leopold Von Ranke (1795-1886). The goal of historical writing is to describe the events "as it really happened" by let the facts of history speak for itself without the involvement of historians. There are some guidelines such as present pure facts, eroding prejudice, avoiding moral judgement and so on [15]. Lord Acton (18341902) states that let historians' illustration about the events similar only to satisfy all parties without any subjective feelings or bias [16].

Dear Doris, your sources years are 1891, 1968, 1970, 2004 and 2013 [11,13-18], while my sources years are 1899, 1900, 1947, 1952, 1968, 1970, 1978, 1998, 1999, 2003, 2007, 2008, 2009, 2012, 2013, 2014 2015, 2015 and 2015 [19-35]. Between these alternating periods, our reference authors cannot standardise whether Sabah a country or not? Source document of the United Nations (UN) entitled Classification of Countries by major area and Region of the World lists Sabah and Sarawak which is an autonomous region as part of the formation of Malaysia. Both in the footnote, not in the article as the name of the country [36]. Do you alert about the status of all other territories in the footnote too? About "Olympic Games" and "Yang Dipertua Negara Sabah" status [37-39] was discussed in my previous article, please refer back. Finally, the question of whether or not Sabah a country from the definition of the Malay Language can be seen from its ability to implement all the features of a country according to historical records, rather than through word of mouth, own book publication, own perception or recognition of individuals only [40]. If we really love our Sabah homeland, we will not betray the struggle of our ancestors, but we continue to maintain their heritage for our children and grandchildren.

\section{References}

1. Iqbal U (2016) Opinion on SSKM and Sabah Country Myth, Arts and Social Sciences Journal 7: 1-2.

2. http://www.ssuuk.com/2016/09/kenyataan-rasmi-sskm-ssuuk-terhadap. $\mathrm{html} l \mathrm{~m}=1$

3. Iqbal U (2015) Sejarah Pemikiran Pandang Ke Timur: Kepentingan Jepun Dalam Pembangunan Sosio-Ekonomi Malaysia (1906-1980) Malaysian Journal of History, Politics and Strategic Studies, 41: 57-93.

4. https://en.oxforddictionaries.com/definition/country

5. http://clearlyexplained.com/countries/index.html

6. http://laman.dbp.gov.my/

7. http://skola.amoskadan.cz/s_aj/AJpdf/aepdf/ae01.pdf
8. Morgan KO (2010) The Oxford History of Britain. Oxford: Oxford University Press.

9. http://www.geocurrents.info/geopolitics/is-a-country-necessarily-a-sovereignstate

10. http://www.livescience.com/33003-how-are-new-countries-established.html

11. Treacher WH, Oxon MA (1891) British Borneo: Sketches of Brunai, Sarawak, Labuan and North Borneo. The Government Printing Department, Journal of the Straits Settlements Branch of the Boyal Asiatic Society, UK.

12. Jasni RM, Bulah CH, Matlani J (2013) Sejarah Parti BERJAYA. Kota Kinabalu: Iris Publishing \& Distributors.

13. Harrisson T (1970) The Prehistory of Borneo. Asian Perspectives

14. Whelan FG (1968) Stories from Sabah History. Singapore: Heinemann Educational Books (Asia) Ltd, Oxford University Press, Singapore.

15. Stockwell AJ (2004) Malaysia. Series B Volume 8. Published for the Institute of Commonwealth Studies in the University of London.

16. Boldt A (2014) Ranke: objectivity and history. Rethinking History 18: 457-474.

17. Acton, Dalberg JEE (1906) Lectures on Modern History. MacMillan and Company Liberty Fund, Inc, London.

18. Nicholas T (1978) Sulu and Sabah: A Study of British Policy towards the Philippines and North Borneo from the Late eighteenth Century. Kuala Lumpur: Oxford University Press, UK

19. Anonymous (2015) July 221963 not the day Sarawak gained independence Prof Leigh. Borneo Post Online, Malasiya.

20. Paul BC (1968) Communal Politics in Malaysian Borneo. The Western Political Quarterly 21: 123-140.

21. Ken DWT (2015) The Name of Sabah and the Sustaining of a New Identity in a New Nation. Archipel, 89: 161-178.

22. Doolittle A (2003) Colliding Discourses: Western Land Laws and Native Customary Rights in North Borneo, 1881-1918. Journal of Southeast Asian Studies 34: 97-126.

23. Doolittle A (1998) Historical and Contemporary Views of Legal Pluralism in Sabah, Malaysia. Common Property Resource Digest 47

24. Ranjit DS (2015) The Formation of Malaysia: Advancing the Theses of Decolonization and Competing Expansionist Nationalisms. Journal of Management Research 7: 209-217

25. Hussainmiya BA (2014) Malcolm MacDonald and Brunei: Diplomacy with Intimacy. Journal of Southeast Asian Studies 45: 393-418.

26. Jenks, Jeremiah W (1900) English Colonial Fiscal System in the Far East American Economic Association 3rd Series, Essays in Colonial Finance by Members of the American Economic Association, 1: 263-303.

27. Kahin, George McT (1947) The State of North Borneo 1881-1946. The Far Eastern Quarterly 7: 43-65.

28. Charles MD, Parton W (2008) The Fork Once Taken: From The British Crown Colony of North Borneo to the Federated State of Sabah, East Malaysia: 19631965: A Creative Memoir. Maryland: Publish America.

29. Yusoff MA (1999) The Politics of centre-state conflict: the Sabah experience under the ruling Sabah Alliance (1963-1976). JEBAT 26: 1-25.

30. Yaakop MRM (2009) Isu Pemisahan Singapura-Malaysia: Rasional Keselamatan Politik. JEBAT 36: 62-89.

31. Aman R (2012) Minda Pelaut dan Kenangan Tanah Leluhur: Kemelayuan Malaysia-Indonesia. Bangi: Penerbit Universiti Kebangsaan Malaysia.

32. Jasni RM, Haji C, Bulah Matlani J (2013) Sejarah Parti BERJAYA. Kota Kinabalu: Iris Publishing \& Distributors.

33. Stephens HM (1899) The Administrative History of the British Dependencies in the Further East. The American Historical Review 4: 246-272.

34. The Economic Weekly August, 301952

35. Tregonning KG (1970) The Philippine Claim to Sabah. JMBRAS 43: 161-170.

36. http://www.unep.org/tunza/tunzachildren/downloads/country-Classification.pdf

37. Antonio Sotomayor (2016) The Sovereign Colony: Olympic Sport, National 
Citation: Iqbal U (2016) Answers to the Official Statement of SSKM-SSU (UK) to Uqbah Iqbal's Article. Intel Prop Rights. S1: 001. doi: 10.4172/23754516.S1-001

Page 3 of 3

Identity, and International Politics in Puerto Rico. Nebraska: University of Nebraska Press Malasiya.

38. David JE (1992) The Legal Status of the International Olympic Committee. Pace International Law Review 4: 97-121.
39. Morse MH (1899) The Administrative History of the British Dependencies in the Further East. The American Historical Review 4: 246-272.

40. Anonymous (2014) Suara dari Negara Sabah. Malay Mail Online, September 23.

This article was originally published in a special issue, International Intellectua Property Law and lits Role in Dispute Resolution handled by Editor. Michael D VanAuker, Faculty of Law University of Pittsburgh, San Francisco, USA 